\title{
Dynamic Analysis of Amyloid $\beta$-Protein in Behaving Mice Reveals Opposing Changes in ISF versus Parenchymal A $\beta$ during Age-Related Plaque Formation
}

\author{
Soyon Hong, ${ }^{1}$ Omar Quintero-Monzon, ${ }^{1}$ Beth L. Ostaszewski, ${ }^{1}$ Daniel R. Podlisny, ${ }^{1}$ William T. Cavanaugh, ${ }^{1}$ Ting Yang, ${ }^{1}$ \\ David M. Holtzman, ${ }^{2}$ John R. Cirrito, ${ }^{2}$ and Dennis J. Selkoe ${ }^{1}$ \\ ${ }^{1}$ Center for Neurologic Diseases, Brigham and Women's Hospital and Harvard Medical School, Boston, Massachusetts 02115, and ${ }^{2}$ Department of \\ Neurology, Developmental Biology, Hope Center for Neurological Disorders, Alzheimer's Disease Research Center, Washington University School of \\ Medicine, St. Louis, Missouri 63110
}

Growing evidence supports the hypothesis that soluble, diffusible forms of the amyloid $\beta$-peptide $(\mathrm{A} \beta)$ are pathogenically important in Alzheimer's disease (AD) and thus have both diagnostic and therapeutic salience. To learn more about the dynamics of soluble $\mathrm{A} \beta$ economy in vivo, we used microdialysis to sample the brain interstitial fluid (ISF), which contains the most soluble A $\beta$ species in brain at steady state, in $>40$ wake, behaving APP transgenic mice before and during the process of A $\beta$ plaque formation (age 3-28 months). Diffusible forms of $A \beta$, especially $A \beta_{42}$, declined significantly in ISF as mice underwent progressive parenchymal deposition of $A \beta$. Moreover, radiolabeled $\mathrm{A} \beta$ administered at physiological concentrations into ISF revealed a striking difference in the fate of soluble $\mathrm{A} \beta$ in plaque-rich (vs plaque-free) mice: it clears more rapidly from the ISF and becomes more associated with the TBS-extractable pool, suggesting that cerebral amyloid deposits can rapidly sequester soluble $\mathrm{A} \beta$ from the ISF. Likewise, acute $\gamma$-secretase inhibition in plaque-free mice showed a marked decline of $\mathrm{A} \beta_{38}, \mathrm{~A} \beta_{40}$, and $\mathrm{A} \beta_{42}$, whereas in plaque-rich mice, $\mathrm{A} \beta_{42}$ declined significantly less. These results suggest that most of the $\mathrm{A} \beta_{42}$ that populates the ISF in plaque-rich mice is derived not from new $\mathrm{A} \beta$ biosynthesis but rather from the large reservoir of less soluble $\mathrm{A} \beta_{42}$ in brain parenchyma. Together, these and other findings herein illuminate the in vivo dynamics of soluble $\mathrm{A} \beta$ during the development of $\mathrm{AD}$-type neuropathology and after $\gamma$-secretase inhibition and help explain the apparent paradox that $\operatorname{CSF} \mathrm{A} \beta_{42}$ levels fall as humans develop AD.

\section{Introduction}

After decades of investigative focus on amyloid plaques in Alzheimer's disease $(\mathrm{AD})$, recent findings have led to a conceptual shift. Emerging evidence suggests that the insoluble amyloid fibrils that comprise plaques may not directly confer neurotoxicity but sequester small, diffusible assemblies of amyloid $\beta$-peptide (A $\beta$ ) that have been shown to potently alter synaptic structure and function (Walsh and Selkoe, 2007). The recognition of $\mathrm{A} \beta$ oligomers as highly bioactive assemblies has furthered interest in

Received June 27, 2011; revised Aug. 9, 2011; accepted Sept. 7, 2011.

Author contributions: S.H. and D.J.S. designed research; S.H., 0.Q.M., B.L.O., D.R.P., and T.Y. performed research; W.T.C. contributed unpublished reagents/analytic tools; S.H., 0.Q.M., B.L.O., D.R.P., and D.J.S. analyzed data; S.H., D.M.H., J.R.C., and D.J.S. wrote the paper.

This work was supported by NIH Grant AG027443 (D.J.S.); Harvard NeuroDiscovery Center Predoctoral Training Fellowship and James L. Rappaport Fellowship (S.H.); NIH Grants AG017574-08S1 (0.Q.M.), AG13956 (D.M.H.), and K01 AG029524 (J.C.R.); and NCRR-CTSA Grant UL1 RR024139 (to Yale Center for Clinical Investigation). We are grateful to Meghana Kamineni and Isaac $\mathrm{Ng}$ for technical assistance and to members of the Selkoe laboratory for critical comments. We thank Lennart Mucke for kindly providing J20 mice; Dominic M. Walsh for AW8 antibody; Elan for 3D6, 2G3 and 21F12 antibodies; and Cynthia A. Lemere and Jeffrey L. Frost for assistance with immunohistochemistry.

D.J.S. is a founding scientist and consultant of Elan.

Correspondence should be addressed to Dr. Dennis J. Selkoe, Harvard Medical School, Center for Neurologic Diseases, Brigham and Women's Hospital, 77 Avenue Louis Pasteur, Boston, MA 02115. E-mail: dselkoe@ rics.bwh.harvard.edu.

DOI:10.1523/JNEUROSCI.3272-11.2011

Copyright $\odot 2011$ the authors $\quad 0270-6474 / 11 / 3115861-09 \$ 15.00 / 0$ detecting and analyzing soluble forms of the peptide for mechanistic, diagnostic, and therapeutic purposes. Although factors other than $A \beta$ dyshomeostasis contribute importantly to the pathogenesis of $\mathrm{AD}$ (Pimplikar et al., 2010), virtually all potentially disease-modifying treatments currently under development are focused on decreasing or neutralizing this neurotoxic peptide. Moreover, a reduced CSF level of $\mathrm{A} \beta_{42}$ in subjects with incipient or very early $\mathrm{AD}$ is one of the most promising biomarkers. Despite this therapeutic and diagnostic focus, we still lack insight into the in vivo economy of the most soluble forms of $\mathrm{A} \beta$ in the brain during the development of AD-type pathology.

Here, we used brain microdialysis in awake and behaving hAPP transgenic ( $\mathrm{tg}$ ) mice to gain an understanding of $A \beta$ dynamics before and during the process of $A \beta$ plaque formation. Brain interstitial fluid (ISF) contains the $\mathrm{A} \beta$ pool that best reflects the physiological secretion and fate of soluble species. Microdialysis in mouse models of $\mathrm{AD}$ and even human subjects is providing important insights into the dynamics of normal ISF $\mathrm{A} \beta$ economy (Brody et al., 2008; Cirrito et al., 2008; Kang et al., 2009) and may help identify the earliest, most subtle $\mathrm{A} \beta$ changes that occur as AD-type neuropathology begins. Given the power of this in vivo sampling method, we performed hippocampal microdialysis on $>40$ freely moving APP transgenic mice of increasing age as a model of cerebral $A \beta$ accumulation, and we searched for changes in the quality and quantity of $\mathrm{A} \beta$ species as the brain 
accrues insoluble deposits and undergoes neuronal and glial injury. We systematically analyzed the nature of endogenous $\mathrm{A} \beta$ over time using sensitive sandwich ELISAs, immunoprecipitation (IP)/Western blotting (WB), native and denaturing PAGE, and size exclusion chromatography (SEC). We then complemented these analyses by assessing the fate of radiolabeled $\mathrm{A} \beta$ microinjected at physiological concentrations as a surrogate of newly secreted $A \beta$, and the results help explain the fall of $A \beta_{42}$ in the CSF of humans with AD. Together, these experiments describe the in vivo dynamics of the most soluble pool of brain $\mathrm{A} \beta$ during the process of $\mathrm{AD}$-type amyloid plaque formation.

\section{Materials and Methods}

Mice. J20 line carrying hAPP minigene with FAD mutations KM670/ $671 \mathrm{NL}$ and V717F (a kind gift from L. Mucke, Gladstone Institute, University of California San Francisco, San Francisco, CA) was maintained on a C57BL6 $\times$ DBA2 background (Mucke et al., 2000). All animal procedures were approved by the Harvard Medical School Institutional Animal Care and Use Committee. Mice of both sexes were used in all experiments.

In vivo $A \beta$ microdialysis. Microdialysis was performed as previously described (Cirrito et al., 2003): intracerebral guides were inserted following the coordinates for left hippocampal placement (bregma: $-3.1 \mathrm{~mm}$, $2.5 \mathrm{~mm}$ lateral to midline, and $1.2 \mathrm{~mm}$ below dura at $12^{\circ}$ angle). Perfusion buffer $[1.5 \%$ bovine serum albumin in artificial CSF (in mM: 1.3 $\mathrm{CaCl}_{2}, 1.2 \mathrm{MgSO}_{4}, 3 \mathrm{KCl}, 0.4 \mathrm{KH}_{2} \mathrm{PO}_{4}, 25 \mathrm{NaHCO}_{3}$, and $122 \mathrm{NaCl}, \mathrm{pH}$ 7.35)] was perfused using probes with $35 \mathrm{kDa}$ molecular weight cutoff (MWCO) membranes (BR-2; Bioanalytical Systems) at flow rates 0.2-1 $\mu \mathrm{l} / \mathrm{min}$ with an infusion syringe pump (Stoelting). Microdialysates (ISF) were collected using a refrigerated fraction collector (Univentor). Mice were kept on $12 \mathrm{~h}$ light/dark cycles, and housed in a Raturn cage system (Bioanalytical Systems), which allowed mice to resume normal activities.

Interpolated zero-flow method. The in vivo percentage recovery was calculated as previously described (Cirrito et al., 2003). ISF was collected from 3- and 24-month-old tg mice while varying the perfusion rates (PR): $1.0,0.8,0.6,0.4$, and $0.2 \mu \mathrm{l} / \mathrm{min}$. A $\beta$ levels were measured using the 6E10 A $\beta$ Triplex ELISA (MesoScale Discovery) and the values obtained at each PR were plotted versus the respective PR. The $100 \%$ recovery (i.e., the theoretical maximal amount of exchangeable ISF A $\beta$ species occurring at a zero PR) was calculated by extrapolating back the curve to a zero-flow rate. Then, for each PR, percentage recovery was determined by calculating how much $\% \mathrm{~A} \beta$ was captured compared with the theoretical $[\mathrm{A} \beta]$ at zero PR.

$A \beta$ ELISA. For 6E10 A $\beta$ Triplex ELISA, we used the MSD 96-well MULTI-SPOT Human (6E10) A $\beta$ Triplex Assay (MesoScale Discovery) following the manufacturer's protocol. Briefly, ISF samples were loaded in duplicates onto MULTI-SPOT microplates precoated with antibodies specific to the $C$ termini of $A \beta_{38}, A \beta_{40}$, and $A \beta_{42}$ and detected with SULFO-TAG-labeled 6E10 antibody. Light emitted upon electrochemical stimulation was read using the SECTOR Imager 2400A. For A $\beta(1-x)$ ELISA, we followed a previously described protocol (Townsend et al., 2011). Nunc MaxiSorp 96-well plates were used with 4 G8 (to $A \beta_{17-24}$; Covance) as capture and biotinylated $82 \mathrm{E} 1$ (to $\mathrm{A} \beta_{1-16}$, IBL) as detection antibodies. Signals were amplified with AttoPhos (Promega) and measured by Victor 2 fluorescent plate reader (PerkinElmer).

Lactate, pyruvate, and glycerol measurements. Levels were measured from ISF sampled at $0.2 \mu \mathrm{l} / \mathrm{min}$ using the CMA600 analyzer at the Yale Center for Clinical Investigation (sensitivities were as follows: lactate 0.02 $\mathrm{mM}$, pyruvate $2 \mu \mathrm{M}$, and glycerol $2 \mu \mathrm{M}$ ).

Mouse brain sample preparation for biochemical analyses. Brains were homogenized using a mechanical Dounce homogenizer with 20 strokes at $4000 \mathrm{rpm}$ in ice-cold TBS (20 mu Tris- $\mathrm{HCl}, 150 \mathrm{~mm} \mathrm{NaCl}, \mathrm{pH} 7.4$ ) and protease inhibitors at 4:1 TBS volume:brain wet weight. Homogenate was centrifuged for $30 \mathrm{~min}$ at $175,000 \times \mathrm{g}$ in a $4^{\circ} \mathrm{C}$ TLA 100.2 rotor on Beckman TL 100 (resulting supernatant is termed TBS extract). Pellet was resuspended in $2 \%$ SDS using an 18 gauge needle, heated at $100^{\circ} \mathrm{C}$ for $10 \mathrm{~min}$ and spun at 21,130 $\times \mathrm{g}$ in an Eppendorf 5435 for $10 \mathrm{~min}$ (resulting supernatant is termed SDS extract). Pellet was washed twice more in
SDS, then incubated with $88 \%$ formic acid (FA) at room temperature for $2 \mathrm{~h}$. Resulting supernatant (FA extract) was diluted $10 \times$ with water and lyophilized.

Immunoprecipitation and Western blot for $A \beta$. ISF and brain extracts (except FA extract, which was lyophilized and directly reconstituted in LDS sample buffer before loading) were immunoprecipitated with AW8 polyclonal antibody to $\mathrm{A} \beta$ (1:100; gift from $\mathrm{D}$. Walsh, Brigham and Women's Hospital) using Protein A (Sigma). For conventional SDSPAGE, a previously described protocol (Shankar et al., 2008) was followed. Samples were electrophoresed using 12\% Bis-Tris gel and MES SDS running buffer (Invitrogen), transferred onto $0.2 \mu \mathrm{m}$ nitrocellulose, boiled, then blotted using monoclonal antibodies $6 \mathrm{E} 10$ (to $\mathrm{A} \beta_{3-8}$; Covance) and 4G8, and visualized using the LiCor Odyssey Infrared Imaging System. For bicine/urea-based SDS-PAGE, a previously described system (Klafki et al., 1996) was modified. Briefly, 11\% T/2.6\% C 8M urea separation gel was overlayered by $11 \% \mathrm{~T} / 2.6 \% \mathrm{C} 4 \mathrm{M}$ urea spacer gel and $4 \%$ $\mathrm{T} / 3.3 \% \mathrm{C}$ comb gel. Gels were run at $12 \mathrm{~mA}$ for $1 \mathrm{~h}$, then $34 \mathrm{~W}$ for $3.8 \mathrm{~h}$. Proteins were transferred to PVDF membranes, boiled then blotted with 6E10 with congo red, and detected using HRP and ECL Plus WB Detection Reagent (GE Healthcare).

Immunohistochemistry of brain sections. J20 APP tg brains at ages 3, 12, and 24 months were fixed with $10 \%$ formalin, paraffin-embedded, then sectioned at $8 \mu \mathrm{m}$ thickness, as previously described (Lemere et al., 2002). R1282 polyclonal antibody was used to stain $A \beta$ and the immunoreactivity was visualized using the Vector Elite horseradish-peroxidase $\mathrm{ABC}$ kit (Vector Laboratories) with diaminobenzidine (Sigma) as the chromogen.

APP Western blotting. Mouse brains of 3- and 24-month-old tg mice and wt littermates were homogenized in $1 \%(\mathrm{v} / \mathrm{v})$ Nonidet P-40 STEN buffer (in mM: $150 \mathrm{NaCl}, 50$ Tris, 2 EDTA) using a Teflon Dounce homogenizer. Brain lysates were loaded onto $4-12 \%$ Bis-Tris gel, electrophoresed with MES SDS running buffer, transferred onto $0.2 \mu \mathrm{m}$ nitrocellulose, then blotted with polyclonal antibody C7 (to full-length APP and its C-terminal fragments) and anti- $\alpha$-tubulin polyclonal antibody (Thermo Scientific).

Size-exclusion chromatography. TBS extracts $(250 \mu \mathrm{l})$ or synthetic A $\beta$ $(2 \mathrm{ng}$ ) were eluted at $0.5 \mathrm{ml} / \mathrm{min}$ from a Superdex $20010 / 300 \mathrm{GL}$ column (GE Healthcare) with $50 \mathrm{~mm}$ ammonium acetate, $\mathrm{pH}$ 8.5. Resulting $1 \mathrm{ml}$ fractions were lyophilized, reconstituted in LDS sample buffer, and heated at $65^{\circ} \mathrm{C}$ for $10 \mathrm{~min}$. Samples were subjected to WB using 3D6 (to $\mathrm{A} \beta_{1-5}$; a gift from Elan) and the LiCor Odyssey Infrared Imaging System or ECL Plus WB Detection Reagent (GE Healthcare).

Compound E treatment. Compound E ( $3 \mathrm{mg} / \mathrm{kg}$; Axxora) was injected intraperitoneally to mice undergoing microdialysis. Half-lives were calculated according to Cirrito et al. (2003).

Radioactivity assay. For ISF experiments, $3 \mu \mathrm{l}$ of $1 \mathrm{~nm}\left[{ }^{125} \mathrm{I}\right]-\beta$-amyloid(1-40) (PerkinElmer) were injected through a combination infusion cannula and microdialysis probe (IBR-2; Bioanalytical Systems) at 0.2 $\mu \mathrm{l} / \mathrm{min}$. ISF was collected hourly at $0.6 \mu \mathrm{l} / \mathrm{min}$, paused during the injection, then restarted $1 \mathrm{~min}$ after injection. For TBS extractions, $5 \mu \mathrm{l}$ of $\left[{ }^{125} \mathrm{I}\right]-\beta$-amyloid( $\left.1-40\right)$ were injected in paired mice (young and old). Brains were harvested for TBS extract preparation $1.5 \mathrm{~h}$ postinjection. ${ }^{125}$ I levels were counted using a LS6500 multipurpose scintillation counter (8 min counts).

Clear native PAGE and subsequent denaturation for SDS-PAGE. TBS extracts were prepared from homogenized brains of 24-month-old tg mice and wt littermates, then subjected to non-denaturing clear native PAGE, which separates proteins with isoelectric point $<7$ based on their intrinsic charge (Wittig and Schägger, 2005). Briefly, samples were electrophoresed using native PAGE 4-16\% Bis-Tris gel (Invitrogen) with Bis-Tris$\mathrm{HCl}, \mathrm{pH}$ 7.0, as anode and Tricine Bis-Tris, $\mathrm{pH}$ 7.0, as cathode buffers. Proteins were then transferred onto $0.2 \mu \mathrm{m}$ PVDF (Millipore), boiled and blotted for $\mathrm{A} \beta$ using monoclonal antibodies $2 \mathrm{G} 3$ and $21 \mathrm{~F} 12$ (to $\mathrm{A} \beta_{33-40}$ and $\mathrm{A} \beta_{33-42}$, respectively; gifts from Elan). For subsequent denaturation, we excised two regions of the native PAGE gel following electrophoresis: the $>300 \mathrm{kDa}$ and the $80-230 \mathrm{kDa}$ [based on NativeMark Unstained Protein Standard (Invitrogen) $]$. The diced gels were heated at $100^{\circ} \mathrm{C}$ in denaturing LDS sample buffer and supernatants were electrophoresed using 12\% BisTris gel and MES SDS running buffer (Invitrogen) for Western blotting 

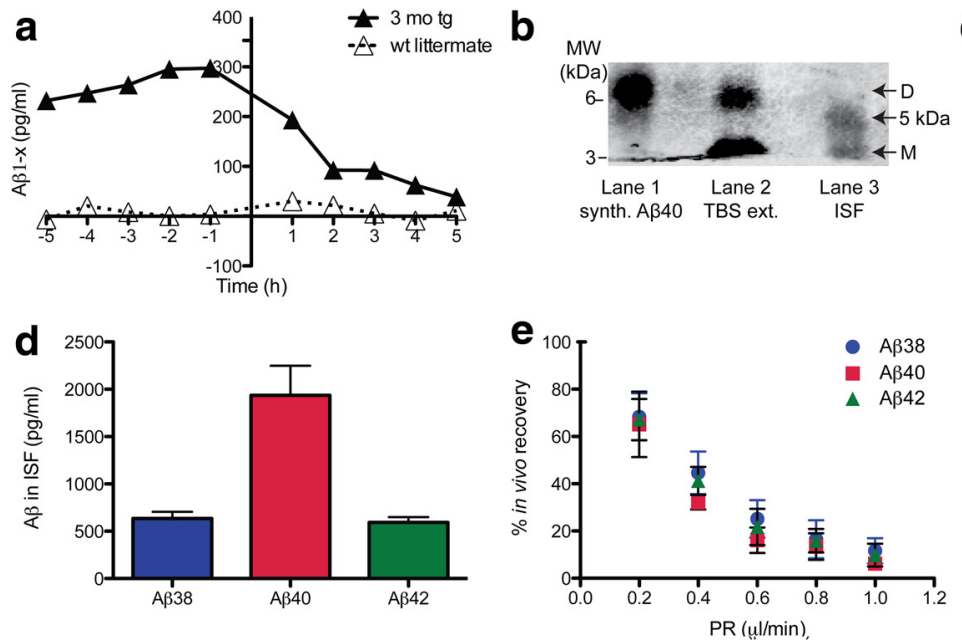

Figure 1. ISF A $\beta$ obtained by microdialysis from behaving 3-month-old J20 hAPP tg mice. $\boldsymbol{a}$, Rapid decline of ISF $A \beta\left(\mathrm{t}_{1 / 2}, \sim 2\right.$ h) upon acute $\gamma$-secretase inhibition in vivo in 3-month-old tg (vs wt littermate) mice. ISF sampled hourly at $1 \mu \mathrm{l} / \mathrm{min}$; Compound E injected at time $=0 \mathrm{~h} . \boldsymbol{b}, \boldsymbol{c}$, ISF collected at $0.2 \mu \mathrm{l} / \mathrm{min}$ were immunoprecipitated with AW8 A $\beta$ antiserum and subjected to two types of SDS-PAGE. $\boldsymbol{b}$, Conventional SDS-PAGE separates ISF A $\beta$ into a $\sim 4 \mathrm{kDa}$ [monomers (M)] and a $\sim 5 \mathrm{kDa} A \beta-$ immunoreactive (lane 3) species. No dimers (D) were detected in ISF, but can be seen in the TBS-extract of a 24-month-old tg mouse (lane 2) or synthetic (synth.) A $\beta$ (lane 1). WB was performed with 6 E10 plus 4G8. c, Bicine/urea SDS-PAGE resolved ISF A $\beta$ into three bands comigrating with synthetic $A \beta_{1-38}, A \beta_{1-40}$, and $A \beta_{1-42}$, plus a fourth faint band corresponding to $A \beta_{1-39}$. WB was performed with 6E10.d, Using 6E10 A $\beta$ triplex ELISA, we quantified $A \beta_{x-38}$, $A \beta_{x-40}$, and $A \beta_{x-42}$ in ISF (mean \pm SEM: $635 \pm$ 70, $1937 \pm 311$, and $592 \pm 58 \mathrm{pg} / \mathrm{ml}$, respectively; $n=7$ mice). $\boldsymbol{e}$, Interpolated zero-flow method (mean \pm SEM; $n=3-4$ mice).

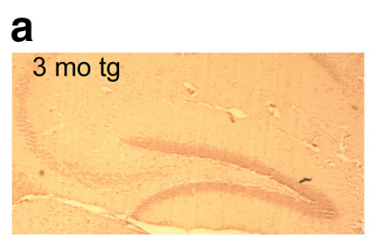

b
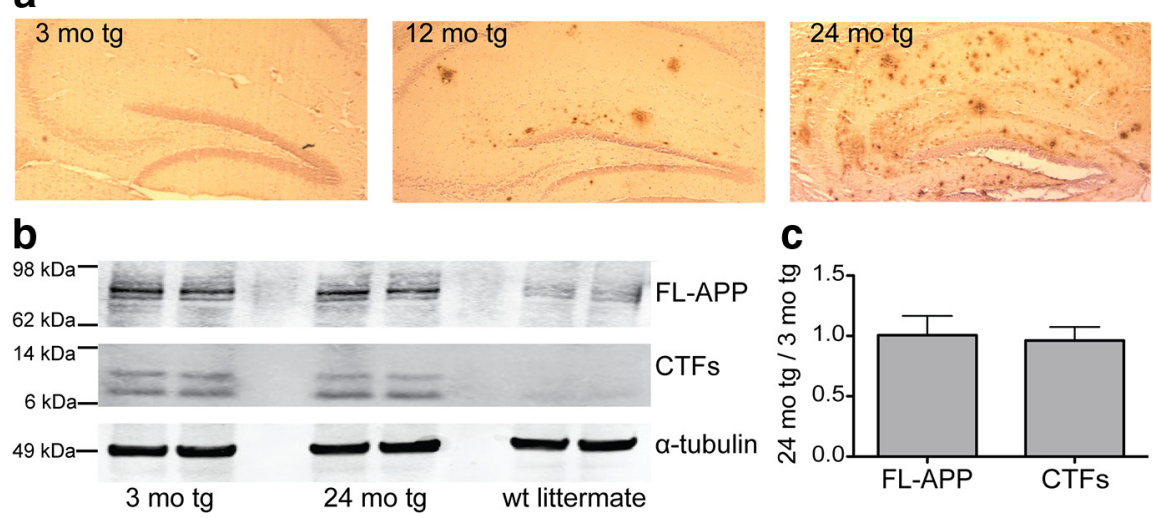

\section{C}

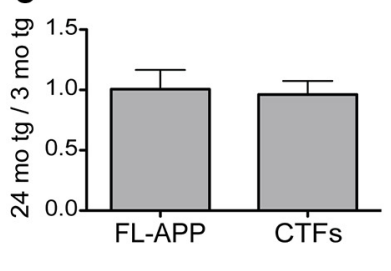

Figure 2. Amyloid plaques develop and mature with age in J20 APP tg mice without significant changes in full-length (FL) APP or in its proteolytic processing by $\beta$ - or $\alpha$-secretases. $\boldsymbol{a}$, Hippocampal sections from fixed J20 APP tg brain were paraffinembedded, then stained for $A \beta$ using R1282 polyclonal antibody. Three-month-old tg sections were virtually plaque-free, whereas some plaques had formed by age 12 months. By 24 months, abundant diffuse and dense-core plaques populated the hippocampus. $\boldsymbol{b}$, Representative blot of brain lysates of 3- and 24-month-old tg mice and wt littermate loaded onto denaturing SDS-PAGE, then blotted for full-length APP and its C-terminal fragments (CTFs) (WB was performed with polyclonal C7) or to $\alpha$-tubulin (WB was performed with polyclonal tubulin- $\alpha$ ). c, Summary ratios of immunoreactive signals at 24- versus 3-monthold tg mice, for full-length APP and C-terminal fragments normalized to the $\alpha$-tubulin signal. $n=3$ mice per group; signal quantification by Licor Odyssey.

using monoclonal antibody 3D6 (to A $\beta_{1-5}$; gift from Elan). Proteins were visualized using the Licor Odyssey Infrared Imaging System.

Statistical analysis. Data were analyzed using PRISM (Graphpad Software) for one- or two-way ANOVA, followed by Bonferroni post hoc test if means were significantly different by ANOVA, or Student's $t$ test, as appropriate.

\section{Results}

Biochemical analysis of $A \beta$ peptides that remain soluble in the brains of young, behaving hAPP transgenic mice To examine the quality and quantity of $\mathrm{A} \beta$ that remains soluble and of low molecular weight in ISF in vivo (termed ISF A $\beta$
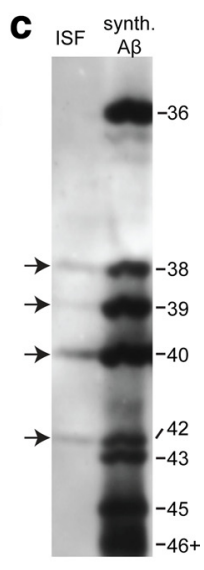

herein), we used a microdialysis probe with a $35 \mathrm{kDa}$ MWCO membrane in mice expressing FAD-mutant human APP [J20 line (Mucke et al., 2000)]. When we intraperitoneally injected Compound E, a potent and brain-penetrant $\gamma$-secretase inhibitor (Grimwood et al., 2005; Yan et al., 2009), total ISF A $\beta$ captured in microdialysates fell rapidly $\left(t_{1 / 2}, \sim 2 \mathrm{~h}\right)$ to baseline (Fig. 1a), showing that most of the ISF $\mathrm{A} \beta$ we sampled by microdialysis in young mice represents newly synthesized APP cleavage products. To capture the $\mathrm{A} \beta$ species that best reflect the physiological levels, we performed microdialysis at a slow perfusion rate of $0.2 \mu \mathrm{l} / \mathrm{min}$ for up to $72 \mathrm{~h}$, as this allows optimal exchange of free $\mathrm{A} \beta$ into the probe. ISF samples were immunoprecipitated with a polyclonal $\mathrm{A} \beta$ antiserum (AW8), and the precipitates were separated by denaturing PAGE and blotted with pooled monoclonal antibodies to the $\mathrm{N}$ terminus (6E10) and midregion (4G8) of $A \beta$. The ISF $A \beta$ was separated by conventional SDS-PAGE into two species: a $4 \mathrm{kDa}$ monomer and a novel $\sim 5 \mathrm{kDa}$ species, which ran approximately half the time as a band (Fig. 1b) and the other half as a smear (Fig. 4a). We did not detect dimers (which run at $\sim 6.5 \mathrm{kDa}$ in these gels; Fig. $1 b$ ) by IP/WB in the ISF of any of the $>40$ mice we examined in this study, regardless of age. In vitro (test tube) microdialysis of synthetic $\mathrm{A} \beta_{40}$ showed that our $35 \mathrm{kDa}$ MWCO membrane allowed passage of dimers; however, their diffusion efficiency was low compared with that of monomers (data not shown), suggesting that the lack of dimers in the ISF samples could be due to the detection limit of the technique. Next, we analyzed the mouse ISF by bicine/urea SDS-PAGE, which electrophoretically separates $\mathrm{A} \beta$ peptides of different lengths (Klafki et al., 1996). ISF $A \beta$ was resolved into three principal bands comigrating with synthetic $\mathrm{A} \beta_{1-38}, \mathrm{~A} \beta_{1-40}$, and $\mathrm{A} \beta_{1-42}$, plus a fourth faint band comigrating with $A \beta_{1-39}$ (Fig. 1c). Using a multiplex ELISA, we confirmed the bicine/urea gel result that $\mathrm{A} \beta_{40}$ is the most abundant $\mathrm{A} \beta$ in ISF (Fig. $1 d)$. The $\mathrm{A} \beta_{42} / \mathrm{A} \beta_{40}$ ratio in the ISF of young, plaque-free $\mathrm{J} 20$ mice was calculated to be $\sim 0.3$. Using the interpolated zero-flow method (Jacobson et al., 1985; Cirrito et al., 2003), we estimated the total soluble $\mathrm{A} \beta$ concentrations in hippocampal ISF of 3-month-old tg mice to be $\sim 1.2 \mathrm{~nm}$ (Fig. $1 e$ ).

ISF $A \boldsymbol{\beta}$ decreases with age as $\mathrm{A} \boldsymbol{\beta}$ in brain parenchyma accrues To elucidate how amyloid plaque development and maturation affect the steady-state levels of brain ISF A $\beta$, we sampled ISF from the hippocampi of living J20 tg mice at three ages: preplaque $(\sim 3$ months), early plaque deposition ( $\sim 12$ months), and abundant and mature plaque deposition ( $\sim 24$ months) (Fig. $2 a)$. The levels 


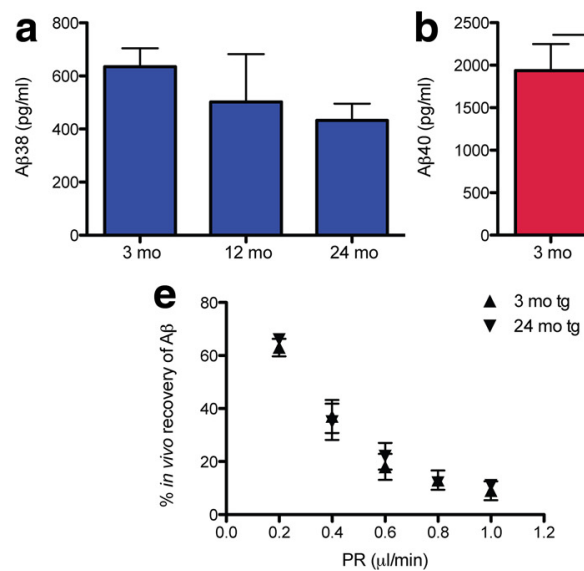

**
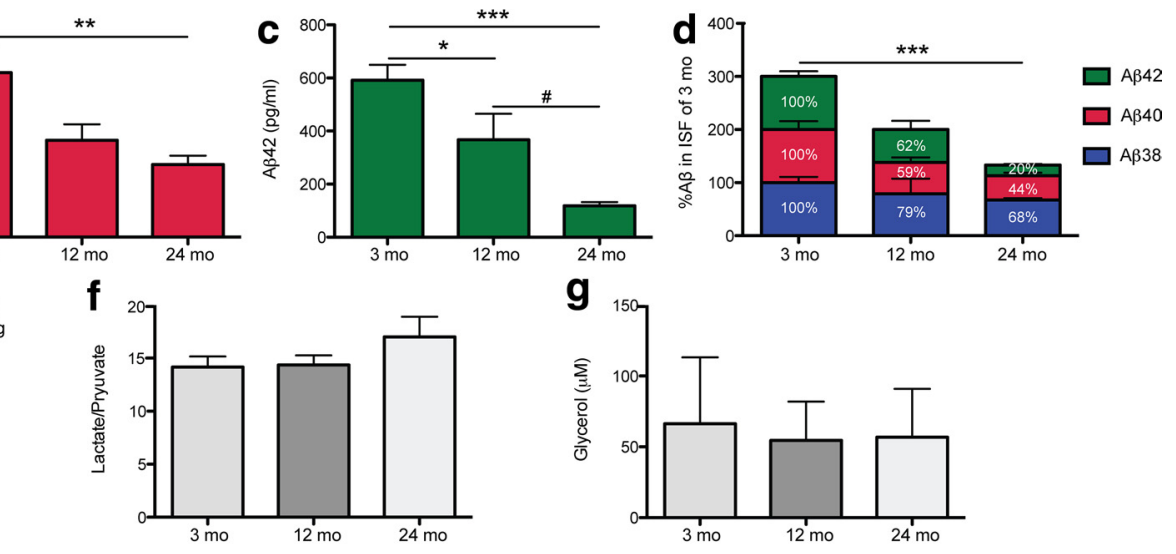

Figure 3. Levels of soluble ISF $A \beta<35 \mathrm{kDa}$ in the brain fall with age. $\boldsymbol{a}$ - $\boldsymbol{d}$, ISF was sampled from the hippocampi of 3- (preplaque), 12- (early plaque deposition), and 24-month old (abundant, mature plaques) J20 tg mice. Using $A \beta$ triplex ELISAs, we found that $A \beta_{x-38}(\boldsymbol{a}), A \beta_{x-40}(\boldsymbol{b})$, and $A \beta_{x-42}(\boldsymbol{c})$ all decreased with age (means \pm SEM; $n=7,4,7$ mice at 3,12 , and 24 months, respectively). One-way ANOVA, followed by Bonferroni test: ${ }^{*} p<0.05$, ${ }^{* *} p<0.01$, and ${ }^{* * *} p<0.001$ versus 3 months values; ${ }^{*} p<0.05$ versus 12 months values. $\boldsymbol{d}$, Proportional levels of $A \beta_{38}$, $A \beta_{40}$, and $A \beta_{42}$, where each peptide was normalized to its level at 3 months. $A \beta_{42}$ declined the most ( $80 \%$ by 24 months vs 3 months). ${ }^{* * *} p<0.0001$ by two-way ANOVA with age as a variant. e, At $0.2 \mu \mathrm{l} / \mathrm{min}$, the perfusion rate used to collect all ISF samples in Figures 3 and 4 , we obtained comparable percentage recoveries of microdialyzable A $\beta$ in the two extreme ages $(\sim 63 \pm 3 \%$ in 3-month-old tg mice and $\sim 66 \pm 2 \%$ in 24-month-old tg mice, means \pm SEM; $n=3-4$ mice). $\boldsymbol{f}, \boldsymbol{g}$, Ratios of lactate to pyruvate $(\boldsymbol{f})$ and glycerol $(\boldsymbol{g})$ levels in the ISF microdialysates were not altered with age (means \pm SEM; $n=3-8$ mice).

Table 1. Theoretical concentrations of microdialyzable ISF $A \beta$ in vivo at zero-flow rate

\begin{tabular}{|c|c|c|c|c|c|c|c|c|}
\hline & $A \beta 38$ & & $A \beta 40$ & & $A \beta 42$ & & $A \beta 42$ & \\
\hline & $3 \mathrm{mo}$ & $24 \mathrm{mo}$ & $3 \mathrm{mo}$ & $24 \mathrm{mo}$ & $3 \mathrm{mo}$ & $24 \mathrm{mo}$ & $3 \mathrm{mo}$ & $24 \mathrm{mo}$ \\
\hline$[$ ISF $A \beta]$ of $J 20 \operatorname{tg}$ mice & 930 & 658 & 2975 & 1231 & 880 & 166 & 0.30 & 0.13 \\
\hline
\end{tabular}

Concentrations of endogenous hippocampal ISF $A \beta_{38}, A \beta_{40}$, and $A \beta_{42}$ were calculated by extrapolating the curves generated from the interpolated zero-flow method to zero PR (Fig. 5). Ratios of $A \beta_{42} / A \beta_{40}$ in the ISF of 3- and 24-month-old tg mice were calculated to be $\sim 0.30$ and 0.13 , respectively, reflecting a higher drop of $A \beta_{42}$ versus $A \beta_{40}$ in 24 -month-old tg mice.

of holoAPP and its C-terminal fragments generated by $\beta$ - and $\alpha$-secretases were constant over the 3 - to 24 -month ISF sampling period (Fig. $2 b$ ), suggesting that $\mathrm{A} \beta$ production via APP proteolytic processing does not change appreciably over age. As quantified by multiplex A $\beta$ ELISA, all three $\mathrm{A} \beta$ peptides measured in ISF $\left(\mathrm{A} \beta_{x-38}, \mathrm{~A} \beta_{x-40}\right.$, and $\left.\mathrm{A} \beta_{x-42}\right)$ decreased over time to levels that were significantly reduced by 24 months (Fig. $3 a-c$ shows absolute values; Fig. $3 d$ shows proportional levels). As the individual peptides fell to different degrees, the $\mathrm{A} \beta_{42} / \mathrm{A} \beta_{40}$ ratio in the ISF shifted from 0.3 at 3 months to 0.13 at 24 months. We estimated that the total soluble $A \beta$ concentrations in hippocampal ISF decreased from $\sim 1.2 \mathrm{nM}$ in 3-month-old tg mice to $\sim 0.5 \mathrm{~nm}$ in 24 month-old tg mice (for concentrations of individual $\mathrm{A} \beta$ peptides in hippocampal ISF of 3- and 24-month-old tg mice, see Table 1). The similar percentage recovery of microdialyzable $\mathrm{A} \beta$ at 3 and 24 months (measured at five flow rates) indicates that the age-dependent decrease in ISF $A \beta$ is not due to technical issues with the microdialysis system (Fig. 3e). We measured analytes other than $\mathrm{A} \beta$ present in the ISF to see whether they are also altered with age, in particular, lactate, pyruvate, and glycerol. The ratio of lactate to pyruvate is
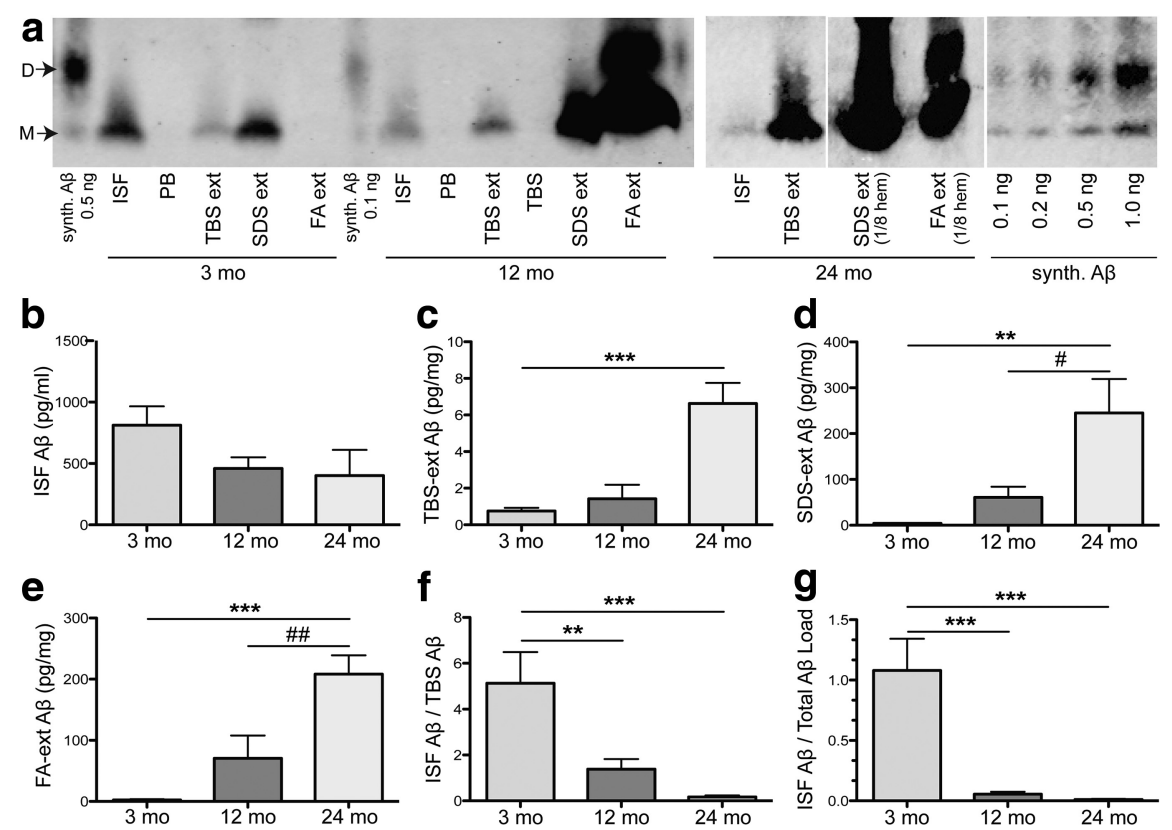

Figure 4. $A \beta$ in all pools of brain parenchyma accrue with age while those that remain diffusible in the ISF dedines. $\boldsymbol{a}$, Representative IP/WBs of A $\beta$ species from brains of the same mice right after microdialysis, in four pools: ISF, TBS extracted (ext), SDS extracted, and FA extracted. All pools (exceptFA extracted, which was lyophilized and straight-loaded onto the gel) were immunoprecipitated with AW8 and blotted with 6E10 and 4G8. Synthetic (synth.) A $\beta$ run alongside for quantification. Perfusion buffer (PB) and TBS were immunoprecipitated as negative controls. $\boldsymbol{b}$ - $\boldsymbol{e}$, Quantification of IP/WBs from 21 mice shows $\sim 50 \%$ decrease in absolute values of ISF $A \beta$ between 3 and 12 months (not significant by one-way ANOVA followed by Bonferroni test) ( $\boldsymbol{b}$ ), with a sharp rise in TBS-(c),SDS- (d) , and FA-(e) extracted A $\beta$ (picograms per milligrams wet brain tissue).f, $\boldsymbol{g}$, Ratios of ISF to TBS-soluble A $\beta(\boldsymbol{f})$ or to total parenchymal A $\beta(\boldsymbol{g})$ calculated for each mouse and shown as mean ratio $\pm \mathrm{SEM} ; n=7$ micepergroup. A $\beta$ quantified by Licor Odyssey imaging and analyzed by one-way ANOVA and Bonferronitest: ${ }^{* *} p<0.01$ and ${ }^{* * *} p<0.001$ versus 3 months; ${ }^{\#} p<0.05$ and ${ }^{\# \#} p<0.01$ versus 12 months. D, Dimers; M, monomers. 

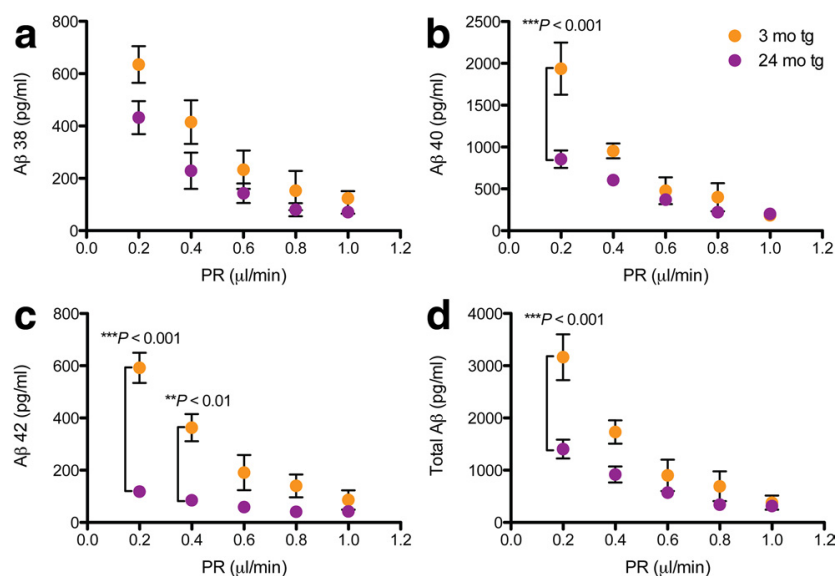

Figure 5. Microdialysis at slower perfusion rates reveals age-dependent changes in ISF A 3 . ISF were collected from hippocampi of 3- (plaque-free) and 24- (plaque-rich) month-old tg mice while varying the PR. Samples were then quantified using 6 E $10 \mathrm{~A} \beta$ triplex ELISA. $\boldsymbol{a}-\boldsymbol{c}$, At PR $1 \mu \mathrm{l} / \mathrm{min}$, no age-dependent changes in any of the three peptides were detectable; however, at slow PRs (especially $0.2 \mu \mathrm{l} / \mathrm{min}$ ), significant differences were noted, particularly in $A \beta_{40}$ and $A \beta_{42}$.d, Sum of the three $A \beta$ peptides measured (total $A \beta$ ). Values are means \pm $\mathrm{SEM}, n=3-7$ mice; $p$ values by two-way ANOVA and Bonferroni test.
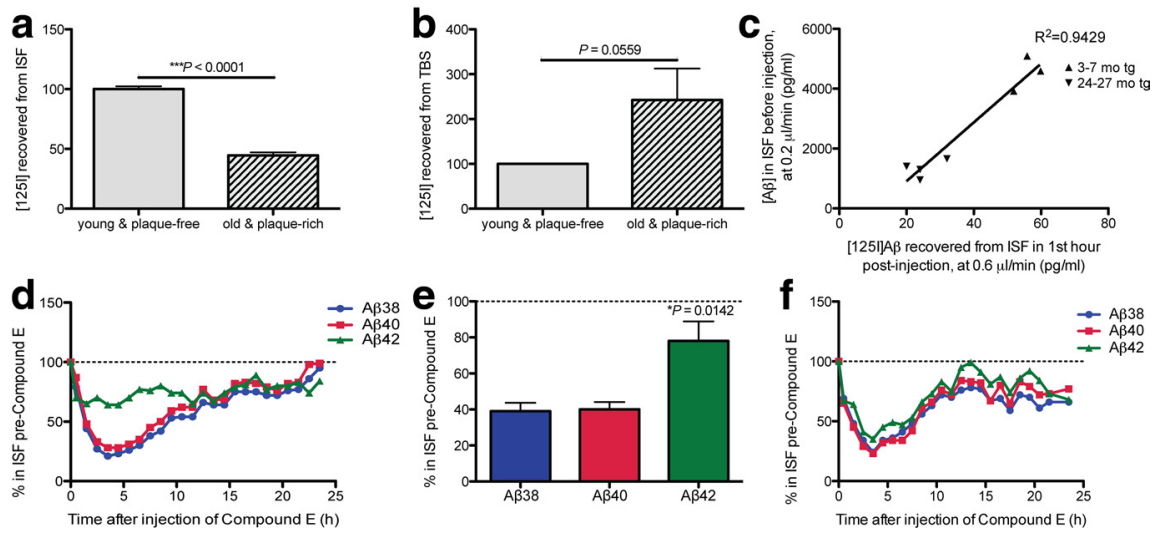

Figure 6. Dynamic shift in the in vivo economy of $A \beta$ once plaques develop. $\boldsymbol{a}-\boldsymbol{c}$, Soluble synthetic $\left[{ }^{125} \mathrm{I}\right] \mathrm{A} \beta_{1-40}$ at a physiological concentration (1 nm) was injected intrahippocampally via a small cannula on the microdialysis probe in awake, behaving mice at ages 3-7 (plaque-free) or 24-27 (plaque-rich) months, and radioactivity was recovered in the ISF by microdialysis (a) and from the TBS extracts of the brains $(\boldsymbol{b})$. Means normalized to amounts in the plaque-free mice $(100 \%) \pm S E M ; n=3-4$ mice per group; $p$ values are one-tailed $t$ tests versus 3-7 months. $c$, Amount of $\left.\left[{ }^{125}\right]\right] A \beta$ recovered in the first hour of injection plotted versus the endogenous $A \beta$ levels sampled from same mice before injection. $\boldsymbol{d}-\boldsymbol{f}$, ISF $A \beta_{42}$ is minimally affected by Compound $E$ in plaque-rich mice. $\boldsymbol{d}$, Representative graph of hourly ISF $A \beta$ levels after Compound E injection ( $0 \mathrm{~h}$ ) into 24-month-old plaque-rich mice while collecting their brain ISF at $0.6 \mu \mathrm{l} / \mathrm{min}$. Levels were normalized to levels of each $A \beta$ species before injection. $\boldsymbol{e}$, Quantification of the individual ISF A $\beta$ peptides in 24-month-old plaque-rich mice for the first $5 \mathrm{~h}$ postinjection (means \pm SEM, $n=3$ mice; $p$ value is by one-way ANOVA). $f$, Hourly ISF A $\beta$ levels after Compound E injection ( $0 \mathrm{~h}$ ) in a 3-month-old plaque-free $\operatorname{tg}$ mouse.

an established marker of the redox state of cells; glycerol is an integral component of cellular membranes, and changes in its level can reflect degradation of membranes (Ungerstedt and Rostami, 2004). Neither the lactate-to-pyruvate ratio nor the level of glycerol in ISF changed significantly during our 3-24 months sampling period (Fig. $3 f, g$ ), suggesting that the decrease in $\mathrm{A} \beta$ is not associated with altered intermediary metabolism or perturbation of cell membrane integrity.

Next, we sought to identify the pathophysiological relationship between ISF A $\beta$ and the accrual of increasingly less soluble $\mathrm{A} \beta$ in brain parenchyma during the development of $\mathrm{AD}$-type neuropathology. Using a sensitive IP/WB method (Walsh et al., 2002; Shankar et al., 2008), we compared the quantity and type of
$\mathrm{A} \beta$ in ISF obtained in vivo with three pools of brain parenchymal $\mathrm{A} \beta$ isolated from the same mice right after the dialysis: TBS extract (traditionally defined as the soluble $A \beta$ fraction), detergent (SDS) extract (aggregated and membrane-associated $\mathrm{A} \beta$ ), and A extract $[\mathrm{A} \beta$ from highly insoluble deposits, including plaque viously for the 20 line and other APP tg mice (Johnson-Wood et al. 2001; Shankar et al.,2009), we observed an age-dependent rise in levels of all three pools of parenchymal A $\beta$ (Fig. 4a). Both the SDS and FA extracts rose sharply with age (Fig. $4 a, d-e$ ). $\mathrm{A} \beta$ in the TBS extract did not rise substantially until 24 months, an age at which we regularly observed SDS-stable dimers in this fraction (Fig. $4 a, c$ ). In contrast to these age-dependent rises in parenchymal $\mathrm{A} \beta$, there was a decline in the ISF. We observed a $50 \%$ decrease in total absolute ISF A $\beta$ levels between 3 and 12 month (Fig. 4b), before there was an appreciable rise in the TBS extract We next analyzed the values in each mouse to determine what portion of its TBS-soluble $\mathrm{A} \beta$ remains dialyzable in vivo, and observed a fivefold decline in the ISF/TBS ratio between 3 and 12 months (Fig. 4f). When normalized to total brain parenchymal $\mathrm{A} \beta$, the relative ISF level declined even more (Fig. $4 g$ ). Thus, all $\mathrm{A} \beta$ pools in brain parenchyma rise with age, while that which remains diffusible in ISF in vivo sharply declines.

\section{Altered dynamics of soluble $\mathrm{A} \beta$ in plaque-rich versus plaque-free mice} Sampling the ISF at slower perfusion rates (which allows for more efficient dialysis of ISF solutes) revealed age-dependent changes in ISF $A \beta$ (Fig. 5). In particular, this method revealed significantly decreased diffusion of endogenous $\mathrm{A} \beta_{40}$ and $\mathrm{A} \beta_{42}$ into the microdialysis probe in 24-month-old compared with 3-month-old mice. To better understand the basis for this marked decrease in recovery of diffusible ISF $A \beta$ in the presence of abundant plaques, we approximated the fate of newly secreted $\mathrm{A} \beta$ molecules by exogenously administering radiolabeled soluble $\mathrm{A} \beta$. We acutely injected soluble synthetic $\left[{ }^{125} \mathrm{I}\right] \mathrm{A} \beta_{1-40}$ at a physiological concentration (1 $\mathrm{nM})$, via a small cannula attached to the microdialysis probe, into the hippocampal ISF of either age 3-7 months (plaque-free) or age 24-27 months (plaquerich). We then measured the ability to recover the radiolabeled peptide from the ISF by microdialysis. From the ISF of the plaque-rich mice, we recovered only $45 \%$ of the injected peptide that was recovered from the ISF of plaque-free mice $(p<0.0001)$ (Fig. $6 a)$. The amounts of the injected $\left[{ }^{125} \mathrm{I}\right] \mathrm{A} \beta$ that were recovered at the two ages correlated well with the respective endogenous $\mathrm{A} \beta$ concentrations in the ISF before injection: the $\left[{ }^{125} \mathrm{I}\right] \mathrm{A} \beta$ levels observed in the first hour and the endogenous $A \beta$ levels just before injection were both high in young mice and low in old mice (Fig. 6b), indicating that the acutely injected radiopeptide achieves a similar equilibrium as the endogenous $\mathrm{A} \beta$ has at steady state. We hypothesized that in plaque-rich mice, the acutely administered monomer is more readily incorporated into their abundant $\mathrm{A} \beta$ deposits and thus is less recoverable in the ISF. To address this idea, we quantified the radioactivity retained in the TBS extracts of brain. We saw a substantially 
higher amount of the fresh, exogenous radiopeptide retained in the TBS extracts of the older mice (Fig. $6 c$ ). In the short time frame we conducted these analyses (i.e., the first 90 min after administration), we did not detect significant levels of radioactivity in the SDS and FA fractions. Together, these results suggest that in plaque-burdened mice, newly generated soluble $\mathrm{A} \beta$ released into the ISF readily accrues onto parenchymal deposits, accounting for its lower steady-state level in the ISF.

The level of ISF $\mathrm{A} \boldsymbol{\beta}_{42}$ in plaque-rich mice is minimally affected by acute $\gamma$-secretase inhibition

To assess whether the ISF A $\beta$ we measured in plaque-rich older mice also represents recent APP cleavage products, as we had determined in young mice (Fig. $1 a)$, we acutely inhibited $\gamma$-secretase in vivo with Compound $\mathrm{E}$. There was a rapid decline of $\mathrm{A} \beta_{38}$ and $\mathrm{A} \beta_{40}(\sim 60 \%$ fall in the first $3 \mathrm{~h} ; \mathrm{t}_{1 / 2}, \sim 1.9 \mathrm{~h}$ and $\sim 2.3 \mathrm{~h}$, respectively), whereas $A \beta_{42}$ declined significantly less $(\sim 20 \%$ fall) (Fig. $6 d, e)$. In contrast, all three peptides fell together in young plaque-free mice during the first $5 \mathrm{~h}$ after shutting down new production with Compound $\mathrm{E}$ (Fig. $6 f$ ). As $\mathrm{A} \beta_{42}$ is the species reported to accumulate much more into plaques than the other, more abundantly generated $\mathrm{A} \beta$ peptides in both $\mathrm{AD}$ patients and APP mice (Iwatsubo et al., 1994; Johnson-Wood et al., 1997), these results suggest that most of the soluble $\mathrm{A} \beta_{42}$ peptide that populates the ISF pool in plaque-rich mice is not derived primarily from new $\mathrm{A} \beta$ biosynthesis but rather from the large reservoir of less soluble $\mathrm{A} \beta_{42}$ in the brain parenchyma. The results also indicate that acute $\gamma$-secretase inhibition is less effective in lowering $\mathrm{A} \beta_{42}$ in plaque-rich brains.

\section{Saline-extractable A $\boldsymbol{\beta}$ of brain parenchyma in its native form appears to exist principally in assemblies $>500$ kDa}

Bicine/urea SDS-PAGE gels showed that the $\mathrm{A} \beta$ peptide distribution differed between the ISF and TBS-extracted pools at all ages (Fig. $7 a$ ). Even at age 3 months, when the brain has virtually no plaques, $\mathrm{A} \beta_{40}$ was the primary $\mathrm{A} \beta$ species in ISF, while, in the TBS-extracted pool, $\mathrm{A} \beta_{42}$ was already the more abundant peptide at steady state, despite the fact that it is generated in much lower amounts than $\mathrm{A} \beta_{40}$ (Fig. 7a). Accordingly, the $\mathrm{A} \beta_{42} / \mathrm{A} \beta_{40}$ ratio differed markedly between the ISF (low ratio) and TBS extract (very high ratio) (Fig. $7 b$ ). This stark difference led us to question the general assumption that the brain $A \beta$ pool that comes into solution upon mechanical homogenization in physiological buffers represents the truly soluble pool (McLean et al., 1999; Walsh and Selkoe, 2004; Shankar et al., 2009). We per-
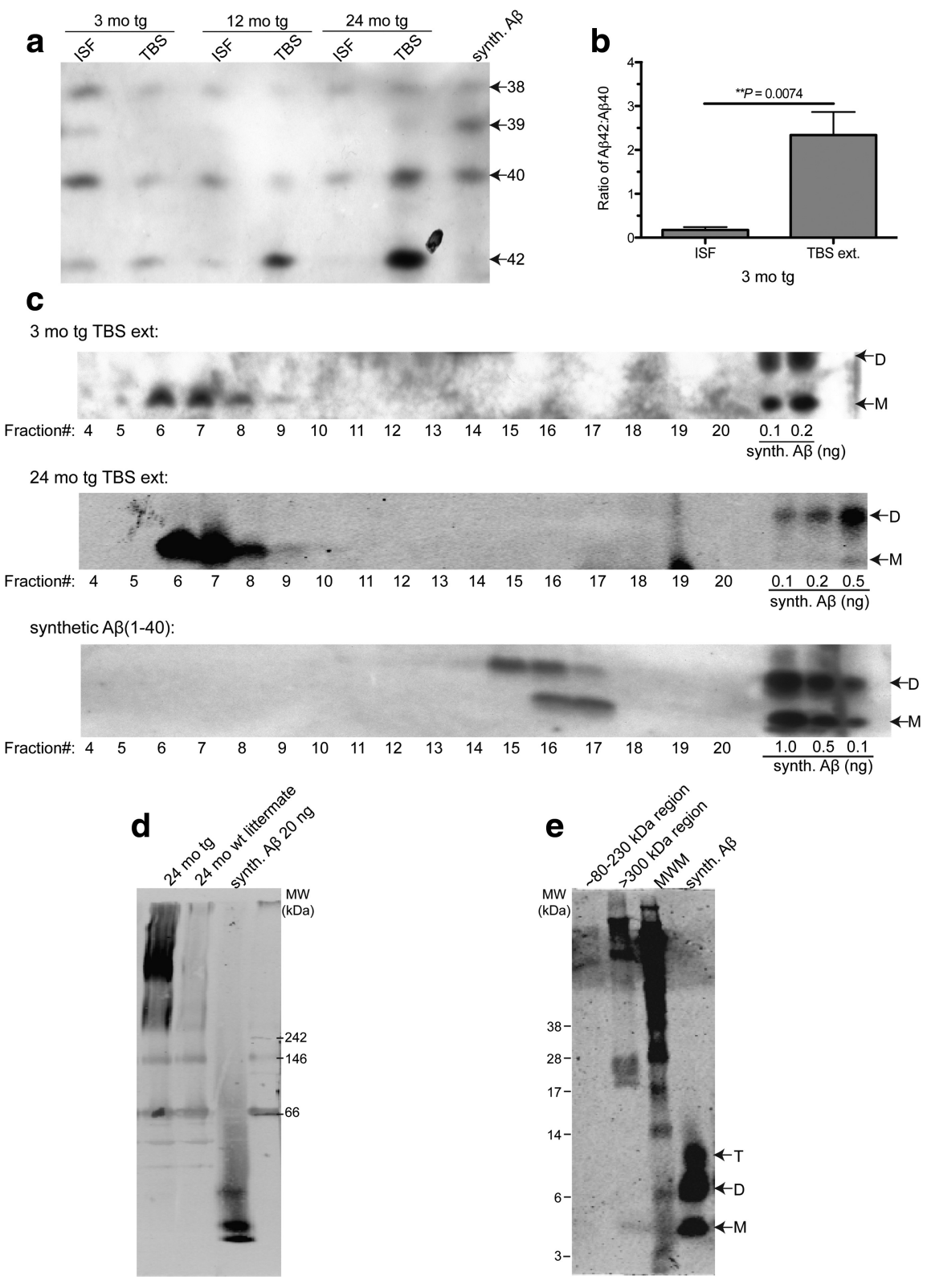

Figure 7. Saline brain extracts of tg mouse exists principally in assemblies $>500 \mathrm{kDa}$ in native form. $\boldsymbol{a}$, Bicine/urea SDS-PAGE shows the principal $A \beta$ peptides present and their relative expression levels in ISF and TBS extracts of 3-, 12-, and 24-month-old tg mice. IP was performed with AW8; WB was performed with 6E10. $\boldsymbol{b}$, Quantification (by ImageJ software) of $A \beta_{42} / A \beta_{40}$ ratios in plaque-free 3-month-old tg mice ( $p$ value by one-tailed $t$ test; $n=3$ each). $c$, Non-denaturing SEC of TBS extracts (ext) of 3 - and 24-month-old tg mice performed on a Superdex 200 SEC column followed by SDS-PAGE of each SEC fraction. Synthetic (synth.) $A \beta_{40}$ run on the same SEC column for comparison. WB was performed with 3D6.d, TBS extracts from a 24-month-old tg mouse and its wt littermate subjected to clear native PAGE and blotted for $A \beta$. WB was performed with $2 G 3$ plus 21F12. e, Excision of the $>300 \mathrm{kDa}$ region and subsequent electrophoresis by denaturing SDS-PAGE showed that this high MW material is disassembled into low MW SDS-stable A $\beta$ species. WB was performed with 3D6. T, Trimers; D, dimers; M, monomers; MWM, MW marker.

formed non-denaturing SEC on the TBS extract and subjected the resultant SEC fractions to SDS-PAGE for WB analysis. Surprisingly, most $\mathrm{A} \beta$ in the TBS extracts of plaque-free ( 3 months $\mathrm{tg}$ ) mice eluted in the void volume of a Superdex 200 SEC column [suggesting a molecular weight $(\mathrm{MW})>500 \mathrm{kDa}$, and this material ran principally as monomers when electrophoresed on a denaturing gel (Fig. 7c, fractions 6 and 7). The SEC elution profiles of TBS extracts from 3- and 24-month-old tg mice were similar and differed sharply from that of synthetic $\mathrm{A} \beta_{40}$ peptide alone (Fig. $7 c$ ). In accordance with this, $A \beta$ in TBS extracts from 24-month-old tg mice ran as an aggregated, high MW complex 

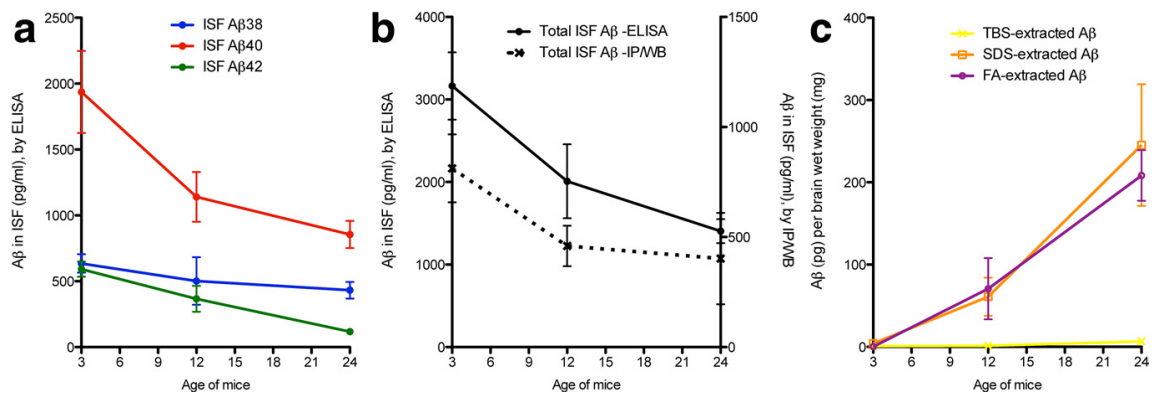

Figure 8. Summary of the temporal changes in the four $A \beta$ brain pools. $\boldsymbol{a}$, Decreases with age in all three in vivo ISF $A \beta$ peptides measured by 6 E10 A $\beta$ triplex sandwich ELISA (for details, see Fig. 3). $\boldsymbol{b}$, The fold-decrease measured by ELISA (significant between ages 3 and 24 months by two-way ANOVA; see Fig. 2) is comparable to the fold-decrease measured by IP/WB (though the latter was not significant by one-way ANOVA; for details, see Fig. 4). The total amount measured by IP/WB analysis method was only 30\% of the total amount measured by ELISA. c, IP/WB analysis of $A \beta$ in brain tissue. By $\sim 24$ months, there was a steep increase in insoluble (SDS- and FA-extracted) $A \beta$. The TBS-extracted $A \beta$ from the same mice did not rise until 24 months and then only very slightly. Values are means \pm SEM from Figures 3 and 4.

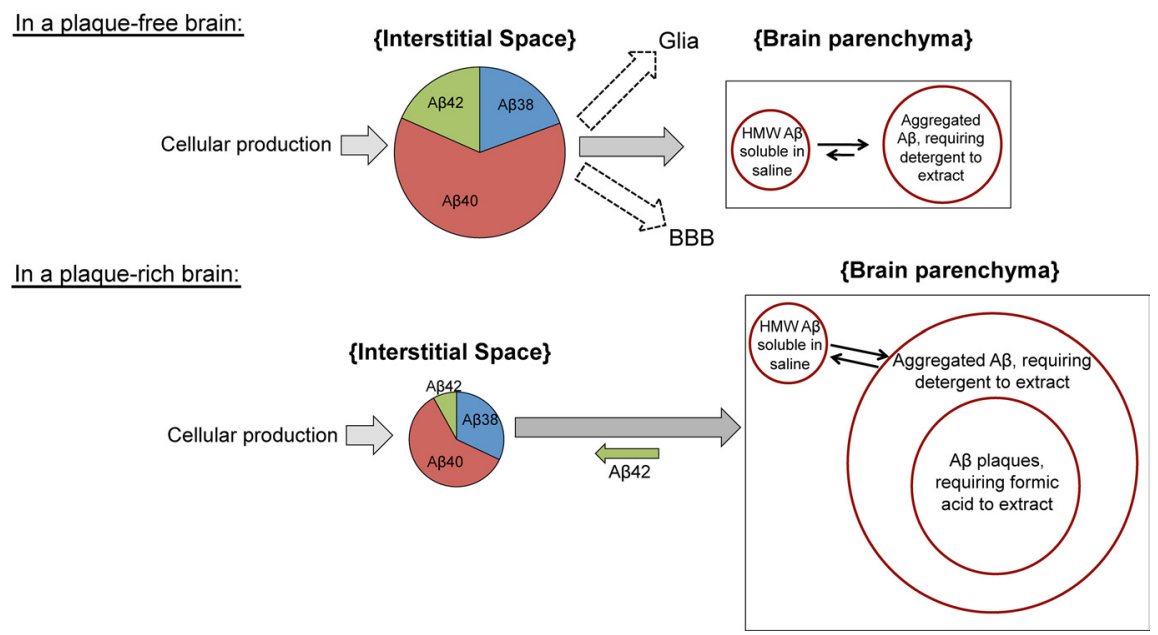

Figure 9. A hypothetical model of $A \beta$ in vivo dynamics before versus after plaque formation based on data herein. Several factors contribute to steady-state $A \beta$ levels in brain ISF. There is a constant supply of $A \beta$ in the ISF pool generated by new APP processing $\left(A \beta_{40} \gg A \beta_{38}=A \beta_{42}>A \beta_{39}\right)$, and this generation appears to change little with age. ISF $A \beta$ can be proteolytically degraded, cleared locally by glia and/or transported across the blood brain barrier (BBB). Soluble $A \beta$ starts aggregating at an early age in brain parenchyma, as evidenced by the $>500 \mathrm{kDa}$ TBS-extractable pool as well as an SDS-extractable pool in 3-month-old plaque-free mice. The most abundant pools in a plaque-free brain are the ISF pool and the SDS-extractable pool. In a plaque-rich brain, however, equilibrium between pools is greatly altered by the overwhelming amount of aggregated $A \beta$, which act as a sink, thereby diminishing the steady-state ISF pool. Plaques may also act as a contributor to the ISF pool, where $A \beta 42$, the most abundant peptide in plaques (and also the most decreased in the ISF) diffuses back into the ISF. HMW, High MW (i.e., >500 kDa).

on a clear native PAGE gel, whereas synthetic $\mathrm{A} \beta_{40}$ ran close to the dye front (Fig. $7 d$ ). Excision of the $>300 \mathrm{kDa}$ region and subsequent denaturation in LDS sample buffer yielded lower MW A $\beta$ species, including monomers (Fig. 7e).

\section{Discussion}

Although factors other than $\mathrm{A} \beta$ dyshomeostasis contribute importantly to the pathogenesis of AD (Pimplikar et al., 2010), most potentially disease-modifying treatments currently under development are focused on decreasing or neutralizing this neurotoxic peptide. Moreover, a reduced CSF level of $\mathrm{A} \beta_{42}$ in subjects with incipient or very early $\mathrm{AD}$ is one of the most promising biomarkers. Despite this therapeutic and diagnostic focus, we still lack insight into the in vivo economy of soluble $A \beta$ in the brain as AD-type pathology forms. Here, we used the powerful method of brain microdialysis in awake, behaving hAPP transgenic mice to gain understanding of the dynamics of the most soluble forms of
$\mathrm{A} \beta$ in the hippocampus before and during the process of $\mathrm{A} \beta$ plaque formation. Our results show that $\mathrm{A} \beta$ peptides, which remain soluble and of low molecular weight in the interstitial fluid in vivo, decrease significantly_-both absolutely (Figs. 3-5, $7 a)$ and especially in relation to the soluble $\mathrm{A} \beta$ extractable from brain membranes (Fig. $4 d$ ) -as plaques accumulate. $\mathrm{A} \beta_{42}$ decreases the most among the three major $\mathrm{A} \beta$ peptides in the ISF; in agreement with this, $\mathrm{A} \beta_{42}$ rises the most in the less soluble $\mathrm{A} \beta$ pools in the brain parenchyma (Figs. $3,7 a)$, keeping with its documented primary role in oligomerization and plaque formation. Figure 8 provides summaries of the temporal changes documented in this study.

Of special clinical relevance is that our discovery of an age-dependent decrease in ISF $\mathrm{A} \beta_{42}$ may be analogous to the widely documented selective decrease in soluble $\mathrm{A} \beta_{42}$ in human (AD) CSF (Motter et al., 1995). In humans, CSF levels of $A \beta_{42}$ appear to relate inversely to amyloid plaque burden, degree of brain atrophy, and severity of cognitive deficits in humans (Motter et al., 1995; Fagan et al., 2009; Shaw et al., 2009). Our dynamic studies of the change in endogenous ISF $A \beta$ and of the fate of radiolabeled $A \beta$ before versus after plaque initiation offer strong evidence from controlled animal experiments for the hypothesis that soluble $\mathrm{A} \beta_{42}$ in humans falls in the CSF because it is sequestered into increasingly insoluble parenchymal deposits as AD develops.

What are the driving forces leading to the sharp decline of diffusible $A \beta$ species as $\mathrm{AD}$-like pathology progresses with age? The constant levels of both full-length APP and the C-terminal fragments generated by $\alpha$ - and $\beta$-secretases suggest that the fall we observe is not due to a decrease of cellular production of $\mathrm{A} \beta$. We also saw no evidence for a perturbation of cell membrane integrity, a change in an indicator of intermediary metabolism, or altered spontaneous behavior (eating, exploring, grooming, etc.) in the mice, arguing against general cytotoxicity or cell death as an explanation for the drop. Thus, we obtained no evidence that decreased neuronal activity or decreased $\mathrm{A} \beta$ production explains the drop in soluble ISF $A \beta$ as mice accrue amyloid deposits. Rather, the decrease in ISF $A \beta$ occurred simultaneously with rises of insoluble $A \beta$ in the SDS- and FA-extractable pools (Figs. 3, 4). Furthermore, the distinct dispositions of soluble radiolabeled $\mathrm{A} \beta$ injected at physiological concentrations directly into the ISF in plaque-free versus plaque-rich animals provide insight into a shift in $\mathrm{A} \beta$ economy: in plaque-rich mice, $A \beta$ becomes rapidly less diffusible and more associated with the loosely membrane-bound (TBS-extractable) pool (Fig. 6). This dynamic shift leads us to hypothesize that once an $\mathrm{A} \beta$ peptide binds to membranes and/or plaques, it is sequestered there and becomes less diffusible, at least temporarily, lead- 
ing to decreased recovery during microdialysis, consistent with a report of lengthened $\mathrm{A} \beta$ clearance time in old versus young APP transgenic mice (Cirrito et al., 2003).

Indirect evidence for a converse pathway suggests that such membrane association is not irreversible. Our finding that upon acute $\gamma$-secretase inhibition there was significantly less fall in ISF, specifically of $\mathrm{A} \beta_{42}$ (which is much more abundant in plaques), suggests that plaques contribute to a dynamic equilibrium between soluble and insoluble $\mathrm{A} \beta_{42}$ pools in the brain and thus help regulate the steady state of ISF A $\beta$ in aged mice (for a model, see Fig. 9). This concept is consistent with evidence that amyloid plaques in APP transgenic mice appear to act as a local reservoir of loosely associated $\mathrm{A} \beta$ that can diffuse from plaques and populate a halo of oligomeric and monomeric $A \beta$ immediately surrounding the amyloid core (Spires et al., 2005; Koffie et al., 2009). It will be interesting to see whether acute alteration of one particular $\mathrm{A} \beta$ pool (e.g., via agents such as antibodies that can selectively bind aggregated $\mathrm{A} \beta$ or agents that only sequester the fully soluble ISF pool) will have transient or lasting effects on the equilibrium maintained among the $\mathrm{A} \beta$ pools.

$\mathrm{A} \beta$ in aqueous extracts of homogenized cerebral cortex has been termed by our group and others as the "soluble A $\beta$ " pool and is thought to be derived from ISF and cytosol, not necessarily from particulates such as amyloid deposits (Gravina et al., 1995; Lue et al., 1999; McLean et al., 1999; Walsh and Selkoe, 2004; Shankar et al., 2009); the rise in this pool was thought to reflect a rise in diffusible $A \beta$ in vivo. However, we show here that $A \beta$ peptides in aqueous parenchymal extracts differ significantly in quality and quantity from those that remain of low MW in the ISF pool. Furthermore, using non-denaturing SEC and native gels, we show that much native A $\beta$ in the TBS extracts of APP transgenic mouse brains, even at a preplaque age of 3 months, exists in assemblies $>500 \mathrm{kDa}$, extending similar data on the aqueous extracts of AD brains (Shankar et al., 2008). Thus, aqueous extracts of $A \beta$ may principally reflect aggregated $A \beta$ peptides bound to cell membranes (in young mice) and to membranes and plaques (in older mice) but which remain water-extractable.

Given this new understanding that aqueous extracts of brain may not reflect the truly diffusible $\mathrm{A} \beta$ species in vivo, it will be important to examine the nature of synaptotoxicity in the different $\mathrm{A} \beta$ pools, including the ISF pool and the TBS-extracted pool, which is currently thought to principally contain the toxic oligomeric species. Interestingly, we have not detected SDS-stable dimers in any of our ISF microdialysates to date, which could be due in part to the limits of detection. Using a test tube model of our microdialysis technique, we found that synthetic $\mathrm{A} \beta$ dimers ( $\sim 8 \mathrm{kDa})$ crossed over the $35 \mathrm{kDa}$ MWCO membrane; however, the diffusion efficiency of dimers was poor compared with that of monomers (data not shown). Therefore, we cannot exclude the existence of low levels of soluble dimers in the ISF of hAPP transgenic mice. Our results may instead suggest that soluble dimers and other oligomers do not actually exist per se in the most diffusible brain pool (ISF); rather, newly formed oligomers (with their exposed hydrophobic amino acids) may distribute quickly onto hydrophobic surfaces (cell membranes and/or amyloid deposits).

As regards the implications of our findings for the pathophysiology of $\mathrm{AD}$, it will be important in future studies to attempt to detect any bioactivity of the ISF A $\beta$ pool at the different plaque stages of APP transgenic mice. Whereas the ISF of young, plaquefree mice acts as a reservoir mainly for the acute cellular production of $A \beta$, ISF in plaque-rich mice seems to be a reservoir for both new $\mathrm{A} \beta$ production and $\mathrm{A} \beta$ that diffuses from membrane- and plaque-bound deposits (as evidenced by the finding that ISF $\mathrm{A} \beta_{42}$ levels do not fall significantly upon acute inhibition of $\gamma$-secretase). Whether the $\mathrm{A} \beta_{42}$ that comes off of parenchymal deposits into the ISF is pathogenically important (compared with $\mathrm{A} \beta$ in the ISF of plaque-free brains) will be important to determine.

In conclusion, these dynamic analyses provide unique insights into the generation of first fully soluble and then increasingly less soluble $\mathrm{A} \beta$ species during age-related accrual of $\mathrm{AD}$-type amyloid deposits in living animals. Based on the usefulness of these preclinical data, we suggest a provocative approach toward potentially extending such studies to humans. Patients with normal pressure hydrocephalus (NPH), which is typified by a clinical triad of subacutely developing dementia, incontinence, and gait ataxia (Relkin et al., 2005; Shprecher et al., 2008), are frequently offered a neurosurgical procedure by which a ventriculoperitoneal shunt is inserted to chronically drain the excess ventricular CSF to the peritoneal cavity and thus potentially improve the patients' NPH symptoms. Several studies of simultaneously obtained cortical biopsies have shown that some or many such shunted patients show amyloid plaques and neurofibrillary tangles indistinguishable from those in typical AD patients (Del Bigio et al., 1997; Bech et al., 1999; Golomb et al., 2000; Hamilton et al., 2010). This co-occurrence suggests that obtaining institutional review board approval to perform a brief (12-24 h) placement of a microdialysis probe at the time of an NPH shunt placement could enable in vivo analysis of ISF A $\beta$ peptides in humans with varying degrees of $A \beta$ deposition. We propose that such controlled clinical research studies in appropriate patients be considered to obtain direct information about the economy of the most soluble species of brain $A \beta$ (those in ISF) as a function of the level of cerebral $\beta$-amyloidosis in humans.

\section{References}

Bech RA, Waldemar G, Gjerris F, Klinken L, Juhler M (1999) Shunting effects in patients with idiopathic normal pressure hydrocephalus; correlation with cerebral and leptomeningeal biopsy findings. Acta Neurochir (Wien) 141:633-639.

Brody DL, Magnoni S, Schwetye KE, Spinner ML, Esparza TJ, Stocchetti N, Zipfel GJ, Holtzman DM (2008) Amyloid-beta dynamics correlate with neurological status in the injured human brain. Science 321:1221-1224.

Cirrito JR, May PC, O’Dell MA, Taylor JW, Parsadanian M, Cramer JW, Audia JE, Nissen JS, Bales KR, Paul SM, DeMattos RB, Holtzman DM (2003) In vivo assessment of brain interstitial fluid with microdialysis reveals plaque-associated changes in amyloid-beta metabolism and halflife. J Neurosci 23:8844-8853.

Cirrito JR, Kang JE, Lee J, Stewart FR, Verges DK, Silverio LM, Bu G, Mennerick S, Holtzman DM (2008) Endocytosis is required for synaptic activity-dependent release of amyloid-beta in vivo. Neuron 58:42-51.

Del Bigio MR, Cardoso ER, Halliday WC (1997) Neuropathological changes in chronic adult hydrocephalus: cortical biopsies and autopsy findings. Can J Neurol Sci 24:121-126.

Fagan AM, Head D, Shah AR, Marcus D, Mintun M, Morris JC, Holtzman DM (2009) Decreased cerebrospinal fluid Abeta(42) correlates with brain atrophy in cognitively normal elderly. Ann Neurol 65:176-183.

Golomb J, Wisoff J, Miller DC, Boksay I, Kluger A, Weiner H, Salton J, Graves W (2000) Alzheimer's disease comorbidity in normal pressure hydrocephalus: prevalence and shunt response. J Neurol Neurosurg Psychiatry 68:778-781.

Gravina SA, Ho L, Eckman CB, Long KE, Otvos L Jr, Younkin LH, Suzuki N, Younkin SG (1995) Amyloid beta protein (Abeta) in Alzheimer's disease brain. J Biol Chem 270:7013-7016.

Grimwood S, Hogg J, Jay MT, Lad AM, Lee V, Murray F, Peachey J, Townend T, Vithlani M, Beher D, Shearman MS, Hutson PH (2005) Determination of guinea-pig cortical gamma-secretase activity ex vivo following the systemic administration of a gamma-secretase inhibitor. Neuropharmacology 48:1002-1011. 
Hamilton R, Patel S, Lee EB, Jackson EM, Lopinto J, Arnold SE, Clark CM, Basil A, Shaw LM, Xie SX, Grady MS, Trojanowski JQ (2010) Lack of shunt response in suspected idiopathic normal pressure hydrocephalus with Alzheimer disease pathology. Ann Neurol 68:535-540.

Hsia AY, Masliah E, McConlogue L, Yu GQ, Tatsuno G, Hu K, Kholodenko D, Malenka RC, Nicoll RA, Mucke L (1999) Plaque-independent disruption of neural circuits in Alzheimer's disease mouse models. Proc Natl Acad Sci U S A 96:3228-3233.

Iwatsubo T, Odaka A, Suzuki N, Mizusawa H, Nukina N, Ihara Y (1994) Visualization of A beta 42(43) and A beta 40 in senile plaques with endspecific A beta monoclonals: evidence that an initially deposited species is A beta 42(43). Neuron 13:45-53.

Jacobson I, Sandberg M, Hamberger A (1985) Mass transfer in brain dialysis devices: a new method for the estimation of extracellular amino acids concentration. J Neurosci Methods 15:263-268.

Johnson-Wood K, Lee M, Motter R, Hu K, Gordon G, Barbour R, Khan K, Gordon M, Tan H, Games D, Lieberburg I, Schenk D, Seubert P, McConlogue L (1997) Amyloid precursor protein processing and A $\beta 42$ deposition in a transgenic mouse model of Alzheimer disease. Proc Natl Acad Sci U S A 94:1550-1555.

Kang JE, Lim MM, Bateman RJ, Lee JJ, Smyth LP, Cirrito JR, Fujiki N, Nishino S, Holtzman DM (2009) Amyloid-beta dynamics are regulated by orexin and the sleep-wake cycle. Science 326:1005-1007.

Kawarabayashi T, Younkin LH, Saido TC, Shoji M, Ashe KH, Younkin SG (2001) Age-dependent changes in brain, CSF, and plasma amyloid (beta) protein in the $\mathrm{Tg} 2576$ transgenic mouse model of Alzheimer's disease. J Neurosci 21:372-381.

Klafki HW, Wiltfang J, Staufenbiel M (1996) Electrophoretic separation of betaA4 peptides (1-40) and (1-42). Anal Biochem 237:24-29.

Koffie RM, Meyer-Luehmann M, Hashimoto T, Adams KW, Mielke ML, Garcia-Alloza M, Micheva KD, Smith SJ, Kim ML, Lee VM, Hyman BT, Spires-Jones TL (2009) Oligomeric amyloid beta associates with postsynaptic densities and correlates with excitatory synapse loss near senile plaques. Proc Natl Acad Sci U S A 106:4012-4017.

Lemere CA, Spooner ET, Leverone JF, Mori C, Clements JD (2002) Intranasal immunotherapy for the treatment of Alzheimer's disease: Escherichia coli LT and LT(R192G) as mucosal adjuvants. Neurobiol Aging 23:991-1000.

Lue LF, Kuo YM, Roher AE, Brachova L, Shen Y, Sue L, Beach T, Kurth JH, Rydel RE, Rogers J (1999) Soluble amyloid beta peptide concentration as a predictor of synaptic change in Alzheimer's disease. Am J Pathol 155:853-862.

Masters CL, Simms G, Weinman NA, Multhaup G, McDonald BL, Beyreuther K (1985) Amyloid plaque core protein in Alzheimer disease and Down syndrome. Proc Natl Acad Sci U S A 82:4245-4249.

McLean CA, Cherny RA, Fraser FW, Fuller SJ, Smith MJ, Beyreuther K, Bush AI, Masters CL (1999) Soluble pool of A $\beta$ amyloid as a determinant of severity of neurodegeneration in Alzheimer's disease. Ann Neurol 46:860-866.

Motter R, Vigo-Pelfrey C, Kholodenko D, Barbour R, Johnson-Wood K, Galasko D, Chang L, Miller B, Clark C, Green R (1995) Reduction of beta-amyloid peptide 42 in the cerebrospinal fluid of patients with Alzheimer's disease. Ann Neurol 38:643-648.

Mucke L, Masliah E, Yu GQ, Mallory M, Rockenstein EM, Tatsuno G, Hu K,
Kholodenko D, Johnson-Wood K, McConlogue L (2000) High-level neuronal expression of Abeta 1-42 in wild-type human amyloid protein precursor transgenic mice: synaptotoxicity without plaque formation. J Neurosci 20:4050-4058.

Pimplikar SW, Nixon RA, Robakis NK, Shen J, Tsai LH (2010) Amyloidindependent mechanisms in Alzheimer's disease pathogenesis. J Neurosci 30:14946-14954.

Relkin N, Marmarou A, Klinge P, Bergsneider M, Black PM (2005) Diagnosing idiopathic normal-pressure hydrocephalus. Neurosurgery 57 [Suppl]:S4-S16; discussion ii-v.

Selkoe DJ, Abraham CR, Podlisny MB, Duffy LK (1986) Isolation of lowmolecular-weight proteins from amyloid plaque fibers in Alzheimer's disease. J Neurochem 46:1820-1834.

Shankar GM, Li S, Mehta TH, Garcia-Munoz A, Shepardson NE, Smith I, Brett FM, Farrell MA, Rowan MJ, Lemere CA, Regan CM, Walsh DM, Sabatini BL, Selkoe DJ (2008) Amyloid- $\beta$ protein dimers isolated directly from Alzheimer's brains impair synaptic plasticity and memory. Nat Med 14:837-842.

Shankar GM, Leissring MA, Adame A, Sun X, Spooner E, Masliah E, Selkoe D, Lemere CA, Walsh DM (2009) Biochemical and immunohistochemical analysis of an Alzheimer's disease mouse model reveals the presence of multiple cerebral Abeta assembly forms throughout life. Neurobiol Dis 36:293-302.

Shaw LM, Vanderstichele H, Knapik-Czajka M, Clark CM, Aisen PS, Petersen RC, Blennow K, Soares H, Simon A, Lewczuk P, Dean R, Siemers E, Potter W, Lee VM, Trojanowski JQ (2009) Cerebrospinal fluid biomarker signature in Alzheimer's disease neuroimaging initiative subjects. Ann Neurol 65:403-413.

Shprecher D, Schwalb J, Kurlan R (2008) Normal pressure hydrocephalus: diagnosis and treatment. Curr Neurol Neurosci Rep 8:371-376.

Spires TL, Meyer-Luehmann M, Stern EA, McLean PJ, Skoch J, Nguyen PT, Bacskai BJ, Hyman BT (2005) Dendritic spine abnormalities in amyloid precursor protein transgenic mice demonstrated by gene transfer and intravital multiphoton microscopy. J Neurosci 25:7278-7287.

Townsend MK, Okereke OI, Xia W, Yang T, Selkoe DJ, Grodstein F (2011) Relation between insulin, insulin-related factors, and plasma amyloid beta peptide levels at midlife in a population-based study. Alzheimer Dis Assoc Disord. Advance online publication. Retrieved May 30, 2011. doi:10.1097/WAD.0b013e31821764ce.

Ungerstedt U, Rostami E (2004) Microdialysis in neurointensive care. Curr Pharm Des 10:2145-2152.

Walsh DM, Selkoe DJ (2004) Deciphering the molecular basis of memory failure in Alzheimer's disease. Neuron 44:181-193.

Walsh DM, Selkoe DJ (2007) A beta oligomers: a decade of discovery. J Neurochem 101:1172-1184.

Walsh DM, Klyubin I, Fadeeva JV, Cullen WK, Anwyl R, Wolfe MS, Rowan MJ, Selkoe DJ (2002) Naturally secreted oligomers of amyloid beta protein potently inhibit hippocampal long-term potentiation in vivo. Nature 416:535-539.

Wittig I, Schägger H (2005) Advantages and limitations of clear-native PAGE. Proteomics 5:4338-4346.

Yan P, Bero AW, Cirrito JR, Xiao Q, Hu X, Wang Y, Gonzales E, Holtzman DM, Lee JM (2009) Characterizing the appearance and growth of amyloid plaques in APP/PS1 mice. J Neurosci 29:10706-10714. 